\title{
Long permanence high altitude airships: the opportunity of hydrogen
}

\author{
Maurizio Bonnici • Alessandro Tacchini • Dean Vucinic
}

Received: 9 September 2012 / Accepted: 13 October 2013 /Published online: 21 November 2013

(C) The Author(s) 2013. This article is published with open access at Springerlink.com

\begin{abstract}
Introduction MAAT cruiser/feeder airship system is a transport system financed by European 7th Framework programme 2011. The project aims to realize a cruiser/feeder airship system, which can connect major populated centres worldwide. The MAAT cruiser feeder system is based on two different airships, the cruiser, which remains airborne for long times, and the feeder, which connects the cruiser with the ground and vice versa. This paper traces a detailed bibliography about MAAT project showing the actual state of the art of the project. This bibliographic review allows understanding the level of innovation related to this project. Methods Starting from the results of the preceding literature, the authors present a model of the cruiser, in terms of both mass and energy. According to the preceding studies, they have assumed the following minimal set of hypothesis: the buoyant gas is hydrogen; the shape of the cruiser is a discoid; operative altitude is in the range $15-17 \mathrm{~km}$. It is well known that the major showstopper to actual diffusion of airships is related to the initial costs related to the use of Helium. The problem is more accentuated in Europe than in USA and Russia, because of higher unitary prices. An economic comparison with the possibility of using Hydrogen has produced. A further comparison has performed in terms of operations, focusing on the necessity of replacing the gas, which disperses in the external atmosphere because of the porosity of the tissues of the balloon system. The on board generation of hydrogen as an energy system is very
\end{abstract}

M. Bonnici $(\bowtie) \cdot$ A. Tacchini

Università di Modena e Reggio Emilia, Di.S.M.I., Via Amendola, 2, 42100 Reggio Emilia, Italy

e-mail: maurizio.bonnici@unimore.it

A. Tacchini

Reggio Emilia Innovazione scarl, Via Sicilia, 31, 42122 Reggio

Emilia, Italy

D. Vucinic

Faculty of Engineering Sciences MECH-ETRO, Vrije Universiteit

Brussel (VUB), Pleinlaan 2, B-1050 Brussels, Belgium convenient on long permanence airships because the replacement buoyant gas can be produced on board. It has been also traced a complete energy balance of the cruiser airship assuming it as discoid. On one side it has been evaluated the hydrolysis process against batteries showing that an hydrolyser/fuell cell cycle has a lower efficiency in comparison of batteries but it looks less expensive and presents a lower weight than any battery type. Results This paper has clearly demonstrated that the use of hydrogen is much more convenient than the uoiuse of Helium, even if it require an accurate design to minimize the risks related to hydrogen potential flammability. It demonstrates the necessity of using hydrogen as buoyant gas in long endurance airships because of the easiness of replacement. An estimation of the necessary energy requirements for a discoid airship has produced demonstrating clearly that a discoid shaped airship is energetically inefficient. These results force to consider a different and more efficient cruiser system.

Conclusions In conclusion this paper demonstrates clearly the necessity of using hydrogen to allow possible future airship renaissance, which could be a fundamental option for the future because of airships are the most energetically efficient aerial vehicles. This research activity has also clearly demonstrated that the initial discoid shaped cruiser hypothesis is not feasible on energetic point of view.

Keywords Airship · Photovoltaic $\cdot$ Hydrogen · Dispersion · Energy balance

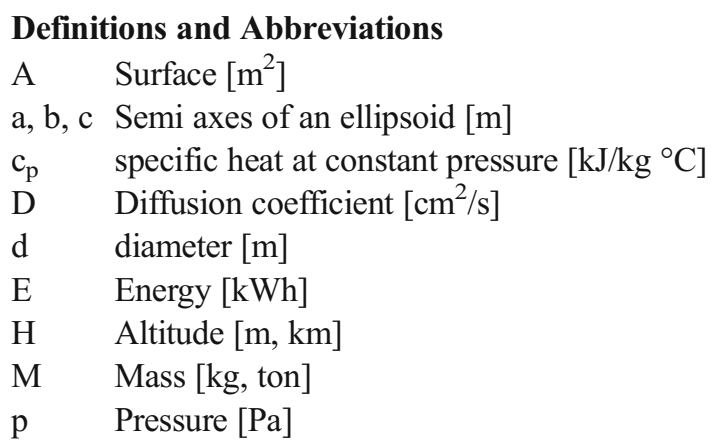


P Permeation coefficient $\left[\mathrm{cm}^{3}{ }_{(273.15 K ; 1.013 \times 105)}\right)^{\prime}$ $(\mathrm{cm} \times \mathrm{S} \times \mathrm{Pa})]$

$\mathrm{R} \quad$ Gas constant $8,314410^{-3} \mathrm{~kJ} / \mathrm{K}$ mol

S Solubility coefficient $\left[\mathrm{cm}^{3}(273.15 \mathrm{~K} ; 1.013 \times 105) /\right.$ $\left.\left(\mathrm{cm}^{3} \times \mathrm{Pa}\right)\right]$

$\mathrm{s} \quad$ thickness $[\mathrm{mm}]$

$\mathrm{T}$ Temperature $[\mathrm{K}]$

$\mathrm{t}$ Time $[\mathrm{s}, \mathrm{h}]$

V Volume $\left[\mathrm{m}^{3}\right]$

$\mathrm{v} \quad$ Wind velocity $[\mathrm{m} / \mathrm{s}]$

\section{Acronyms}

MAAT Multibody Advanced Airship for Transport PV Photovoltaic

\section{Introduction: the MAAT project}

MAAT, Multibody Advanced Airship for Transport, aims to investigate aerial transportation possibility by airship based cruiser-feeder system [1-5]. MAAT is composed by two modules: The cruiser, named PTAH, (acronym of Photovoltaic Transport Aerial High altitude system); the feeder, named ATEN (Aerial Transport Elevator Network feeder), is a VTOL system (Vertical Take Off and Landing) which ensure the connection between the cruiser and the ground. They can lift up and down by the control of buoyancy force and displace horizontally to join to cruiser.

The project aims to:

1. identify and design the most functional cruiser/feeder airship architecture based on a discoid innovative airship able to remain airborne for long periods and to travel great distances;

2. design the best type of propulsion both for cruiser and feeder so they can contribute together to the propulsion of an innovative modular airship;

3. minimize the environmental air transport impacts by annulling the fossil fuels energy consumption by designing both cruiser and feeder are energetically autonomous by photovoltaic energy and innovative electric propulsion.

4. study the different possible ways of approaching and joining between ATEN and PTAH, and consequently, the release of ATEN from PTAH.

5. design the best procedure of docking operations thus identified in order to obtain the minimum disruption to passengers and the maximum safety for themselves and for goods

6. study the different architectures of PTAH and Athens, in such a way that :

a. the lift up capacity guaranteed by the buoyancy force, may be integrated with the power of the engines;

b. effective and safe procedures for docking;
Table 1 Atmospheric data

\begin{tabular}{lllll}
\hline $\begin{array}{l}\text { Altitude } \\
{[\mathrm{m}]}\end{array}$ & $\begin{array}{l}\text { Temperature } \\
{[\mathrm{K}]}\end{array}$ & $\begin{array}{l}\text { Pressure } \\
{[\mathrm{Pa}]}\end{array}$ & $\begin{array}{l}\text { Density } \\
{[\mathrm{kg} / \mathrm{m} 3]}\end{array}$ & $\begin{array}{l}\text { Pressure H2 } \\
{[\mathrm{Pa}]}\end{array}$ \\
\hline 0.00 & 288.15 & 101325.00 & 1.2250 & 106391.25 \\
1000.00 & 281.65 & 89874.57 & 1.1116 & 94368.30 \\
2000.00 & 275.15 & 79495.22 & 1.0065 & 83469.98 \\
3000.00 & 268.65 & 70108.54 & 0.9091 & 73613.97 \\
4000.00 & 262.15 & 61640.24 & 0.8191 & 64722.25 \\
5000.00 & 255.65 & 54019.91 & 0.7361 & 56720.91 \\
6000.00 & 249.15 & 47181.03 & 0.6597 & 49540.08 \\
7000.00 & 242.65 & 41060.74 & 0.5895 & 43113.78 \\
8000.00 & 236.15 & 35599.81 & 0.5252 & 37379.80 \\
9000.00 & 229.65 & 30742.46 & 0.4663 & 32279.58 \\
10000.00 & 223.15 & 26436.27 & 0.4127 & 27758.08 \\
11000.00 & 216.65 & 22632.06 & 0.3639 & 23763.67 \\
12000.00 & 216.65 & 19330.41 & 0.3108 & 20296.93 \\
13000.00 & 216.65 & 16510.41 & 0.2655 & 17335.93 \\
14000.00 & 216.65 & 14101.80 & 0.2268 & 14806.89 \\
15000.00 & 216.65 & 12044.57 & 0.1937 & 12646.80 \\
$\mathbf{1 6 0 0 0 . 0 0}$ & $\mathbf{2 1 6 . 6 5}$ & $\mathbf{1 0 2 8 7 . 4 6}$ & $\mathbf{0 . 1 6 5 4}$ & $\mathbf{1 0 8 0 1 . 8 3}$ \\
17000.00 & 216.65 & 8786.68 & 0.1413 & 9226.02 \\
\hline
\end{tabular}

Bold indicates the valuesat optimal altitude

c. ATEN can land and take off from Airport Hubs named AHA located in major populated centres

d. PTAH satisfies the better possible aerodynamic performances possible for the dimensions and the operative mission.

To study the transfer operations between ATEN and PTAH of goods and people and vice versa, to:

1. minimize distress conditions for passengers,

2. maximize performances especially for goods;

Table 2 Airship system weight

\begin{tabular}{lrr}
\hline & Number of persons & Mass $(\mathrm{kg})$ \\
\hline Passengers & 480 & 48000 \\
Crew & 20 & 2500 \\
Freight & & 12000 \\
Total passengers and freights & 62500 \\
Structure & 150000 \\
Energy conversion & 60000 \\
Energy storage & 50000 \\
Propulsion & 40000 \\
Total System Weight & 300000 \\
Total Weight & 362500 \\
\hline
\end{tabular}


Table 3 Volume comparison $\mathrm{H}_{2}$ vs. $\mathrm{He}$

\begin{tabular}{llllllr}
\hline $\begin{array}{l}\text { Altitude } \\
{[\mathrm{m}]}\end{array}$ & $\begin{array}{l}\text { Density } \mathrm{H}_{2} \\
\mathrm{~kg} / \mathrm{m} 3\end{array}$ & $\begin{array}{l}\text { Density He } \\
\mathrm{kg} / \mathrm{m} 3\end{array}$ & $\begin{array}{l}\mathrm{V}\left(\mathrm{H}_{2}\right) \\
{[\mathrm{m} 3]}\end{array}$ & $\begin{array}{l}\text { Veff }\left(\mathrm{H}_{2}\right) \\
{[\mathrm{m} 3]}\end{array}$ & $\begin{array}{l}\mathrm{V}(\mathrm{He}) \\
{[\mathrm{m} 3]}\end{array}$ & $\begin{array}{l}\text { Veff }(\mathrm{He}) \\
{[\mathrm{m} 3]}\end{array}$ \\
\hline 0.00 & 0.08953 & 0.17777 & 319251 & 351176 & 346150 & 380765 \\
1000.00 & 0.08125 & 0.16132 & 351806 & 386986 & 381448 & 419593 \\
2000.00 & 0.07356 & 0.14606 & 388561 & 427417 & 421300 & 463430 \\
3000.00 & 0.06644 & 0.13193 & 430176 & 473194 & 466421 & 513064 \\
4000.00 & 0.05987 & 0.11887 & 477437 & 525181 & 517665 & 569431 \\
5000.00 & 0.05380 & 0.10682 & 531278 & 584406 & 576042 & 633647 \\
6000.00 & 0.04821 & 0.09573 & 592821 & 652104 & 642771 & 707048 \\
7000.00 & 0.04308 & 0.08555 & 663413 & 729754 & 719310 & 791241 \\
8000.00 & 0.03838 & 0.07621 & 744681 & 819149 & 807425 & 888168 \\
9000.00 & 0.03408 & 0.06767 & 838607 & 922467 & 909265 & 1000192 \\
10000.00 & 0.03016 & 0.05989 & 947603 & 1042364 & 1027446 & 1130190 \\
11000.00 & 0.02660 & 0.05281 & 1074645 & 1182109 & 1165191 & 1281710 \\
12000.00 & 0.02272 & 0.04511 & 1258196 & 1384016 & 1364208 & 1500629 \\
13000.00 & 0.01940 & 0.03853 & 1473098 & 1620408 & 1597218 & 1756939 \\
14000.00 & 0.01657 & 0.03291 & 1724708 & 1897178 & 1870027 & 2057029 \\
15000.00 & 0.01415 & 0.02811 & 2019282 & 2221211 & 2189421 & 2408363 \\
16000.00 & 0.01209 & 0.02401 & 2364179 & 2600597 & 2563378 & 2819716 \\
17000.00 & 0.01033 & 0.02050 & 2767981 & 3044779 & 3001202 & 3301323 \\
\hline & & & & &
\end{tabular}

3. enhance safety of these operations to maximum possible level.

The objectives described are congruent with each other and to achieve this study of the system and components must be highly structured.

\section{MAAT design activity}

This project has started by a preliminary conceptual design activity. The historical milestone references for any author who approaches the design of airships are certainly Lewitt [5] and Warner [6]. Kreider [7] has defined the most

Table 4 Reference values for calculation

\begin{tabular}{|c|c|c|c|c|c|c|c|c|c|c|c|}
\hline $\begin{array}{l}\text { Altitude } \\
{[\mathrm{m}]}\end{array}$ & $\begin{array}{l}\mathrm{c}\left(\mathrm{H}_{2}\right) \\
{[\mathrm{m}]}\end{array}$ & $\begin{array}{l}\mathrm{c}(\mathrm{He}) \\
{[\mathrm{m}]}\end{array}$ & $\begin{array}{l}\mathrm{A} \\
{\left[\mathrm{m}^{2}\right]}\end{array}$ & $\begin{array}{l}\mathrm{A}_{\text {front }}\left(\mathrm{H}_{2}\right) \\
{\left[\mathrm{m}^{2}\right]}\end{array}$ & $\begin{array}{l}\mathrm{A}_{\text {front }}(\mathrm{He}) \\
{\left[\mathrm{m}^{2}\right]}\end{array}$ & $\begin{array}{l}\mathrm{d}_{\mathrm{id}}\left(\mathrm{H}_{2}\right) \\
{[\mathrm{m}]}\end{array}$ & $\begin{array}{l}\mathrm{d}_{\mathrm{id}}(\mathrm{He}) \\
{[\mathrm{m}]}\end{array}$ & $\begin{array}{l}\mathrm{V}^{\wedge} 2 / 3\left(\mathrm{H}_{2}\right) \\
{\left[\mathrm{m}^{2}\right]}\end{array}$ & $\begin{array}{l}\mathrm{V}^{\wedge} 2 / 3(\mathrm{He}) \\
{\left[\mathrm{m}^{2}\right]}\end{array}$ & $\begin{array}{l}\mathrm{V}^{\wedge} 1 / 3\left(\mathrm{H}_{2}\right) \\
{\left[\mathrm{m}^{\wedge} 2\right]}\end{array}$ & $\begin{array}{l}\mathrm{V}^{\wedge} 1 / 3(\mathrm{He}) \\
{\left[\mathrm{m}^{\wedge} 2\right]}\end{array}$ \\
\hline 0.00 & 4.28 & 4.64 & 124920 & 1881.30 & 2039.81 & 5.02 & 5.41 & 4977.56 & 5253.37 & 70.55 & 72.48 \\
\hline 1000.00 & 4.71 & 5.11 & 125016 & 2073.14 & 2247.82 & 5.50 & 5.92 & 5310.44 & 5604.70 & 72.87 & 74.86 \\
\hline 2000.00 & 5.21 & 5.64 & 125130 & 2289.73 & 2482.66 & 6.02 & 6.49 & 5674.15 & 5988.56 & 75.33 & 77.39 \\
\hline 3000.00 & 5.76 & 6.25 & 125268 & 2534.97 & 2748.56 & 6.61 & 7.12 & 6072.39 & 6408.86 & 77.93 & 80.06 \\
\hline 4000.00 & 6.40 & 6.94 & 125435 & 2813.47 & 3050.52 & 7.27 & 7.83 & 6509.37 & 6870.06 & 80.68 & 82.89 \\
\hline 5000.00 & 7.12 & 7.72 & 125637 & 3130.75 & 3394.54 & 8.01 & 8.62 & 6989.99 & 7377.31 & 83.61 & 85.89 \\
\hline 6000.00 & 7.94 & 8.61 & 125883 & 3493.41 & 3787.76 & 8.84 & 9.51 & 7519.88 & 7936.57 & 86.72 & 89.09 \\
\hline 7000.00 & 8.89 & 9.64 & 126185 & 3909.40 & 4238.79 & 9.78 & 10.50 & 8105.59 & 8554.72 & 90.03 & 92.49 \\
\hline 8000.00 & 9.98 & 10.82 & 126557 & 4388.30 & 4758.04 & 10.83 & 11.63 & 8754.71 & 9239.82 & 93.57 & 96.12 \\
\hline 9000.00 & 11.24 & 12.18 & 127018 & 4941.79 & 5358.17 & 12.02 & 12.89 & 9476.20 & 10001.28 & 97.35 & 100.01 \\
\hline 10000.00 & 12.70 & 13.77 & 127592 & 5584.09 & 6054.59 & 13.36 & 14.32 & 10280.47 & 10850.11 & 101.39 & 104.16 \\
\hline 11000.00 & 14.40 & 15.61 & 128311 & 6332.73 & 6866.31 & 14.87 & 15.93 & 11179.91 & 11799.40 & 105.74 & 108.63 \\
\hline 12000.00 & 16.86 & 18.28 & 129439 & 7414.37 & 8039.08 & 16.98 & 18.16 & 12419.21 & 13107.37 & 111.44 & 114.49 \\
\hline 13000.00 & 19.74 & 21.40 & 130884 & 8680.76 & 9412.17 & 19.35 & 20.66 & 13795.89 & 14560.33 & 117.46 & 120.67 \\
\hline 14000.00 & 23.11 & 25.06 & 132731 & 10163.46 & 11019.80 & 21.97 & 23.43 & 15325.17 & 16174.36 & 123.79 & 127.18 \\
\hline 15000.00 & 27.05 & 29.33 & 135089 & 11899.34 & 12901.95 & 24.89 & 26.49 & 17023.93 & 17967.24 & 130.48 & 134.04 \\
\hline 16000.00 & 31.68 & 34.34 & 138091 & 13931.77 & 15105.62 & 28.09 & 29.86 & 18911.04 & 19958.91 & 137.52 & 141.28 \\
\hline 17000.00 & 37.09 & 40.21 & 141901 & 16311.32 & 17685.66 & 31.61 & 33.53 & 21007.31 & 22171.34 & 144.94 & 148.90 \\
\hline
\end{tabular}


Table 5 Reference photovoltaic plant considered for hydrogen production

\begin{tabular}{lll}
\hline Module Properties & poly-Si & \\
\cline { 2 - 3 } Module & Unit & Value \\
\hline Power capacity & $\mathrm{W}$ & 200 \\
Efficiency & $\%$ & $13.50 \%$ \\
Area & $\mathrm{m}^{2}$ & 1.48 \\
Nominal operating cell temp. & ${ }^{\circ} \mathrm{C}$ & 45 \\
Temperature coefficient & $\% /{ }^{\circ} \mathrm{C}$ & $0.40 \%$ \\
Plant and Conversion Properties & & \\
Plant & $\mathrm{Unit}$ & Value \\
Miscellaneous losses & $\%$ & $5.00 \%$ \\
Inverter & $\mathrm{Unit}$ & Value \\
Efficiency & $\%$ & $95.00 \%$ \\
Capacity & $\mathrm{kW}$ & 1 \\
Distribution Losses & $\%$ & $5.00 \%$ \\
\hline
\end{tabular}

comprehensible mathematical modeling of an High Altitude Balloon and allowed to predict the Performance during flight.

The fundamental guidelines about airship designs has synthesized by Khoury and Gillett [8].

The actual aeronautic guidelines has been defined by Raymer [9], with the conceptual design for innovation method. This methodology can be partially reassumed by the acronym KISS that means "keep it simple, stupid". It is not a simple joke. In any breakthrough innovation it is important to adopt a step by step design starting from very basic model and then introducing individual modification, which can be tested individually inside the system.

The intrinsic difficulties related to the project has forced to produce a large conceptual and design innovation in different field starting from the basic principles. Krausman [10] has investigated various parameters affecting altitude performance of tethered aerostats. Colozza $[11,12]$ have studied several models of high altitude airships. In particular he has investigated the possibility of realizing high altitude photovoltaic airships. This studies has inspired the PSICHE project about photovoltaic energy production and conversion at high altitude [13], and the energetic design based of high- altitude airships by Dumas [14]. PSICHE can be considered the original cruiser/feeder high altitude system which has been the origin of the MAAT project constituted by two very specialized systems. The cruiser needs to be designed an airship with cruising capability, while the feeder is conceived by simplicity as an aerostat with possibility of control by propulsion. Similar results has been produced by Aglietti and others [15], who have studied the feasibility of solar power generation using high altitude platforms. Dumas and Trancossi [16] has formulated an improved mathematical model used for PSICHE energetic evaluation, estimating the photovoltaic energy, which can be produced at high altitude by an horizontal photovoltaic plant, both in terms of electric energy or hydrogen and oxygen. In particular this method has been also recently improved [17] by a more complete estimation of the plants and their energetic effects on the system.

Pascoa [17] has produced an effective analysis of possible propulsion concepts which can be adopted on unconventional airships defining an effective state of the art which can be starting point for future development of future airship design modes.

Trancossi and others [18] has presented a variable shape airship configuration, which permits to reduce both the risk of fire and presents also a variable frontal section increasing volume with altitude, such as a traditional aerostat. Dumas and others [19, 20] have presented two different studies on this airship concept, verifying also its optimal mission profile and its feasibility.

The difficulties related to the energetic balances related to unconventional high altitude airships has been analysed by Pshikhopov [21, 22] and confirmed by Dumas [23, 24] and Khoshnoud [20, 25]. The exigency of producing an effective optimization of the plants and the consequent design guidelines have been demonstrated by Smith [26, 27]. This problematic part of the project has been an exceptional opportunity for the future of the project development opening the road to a series of methodological innovations.

Two directions has then started: a traditional disciplinary process which aims to improve the results on the basis of specific disciplinary needs which has been produced an interesting series of minor improvements starting from the very interesting stability analysis by Voloshin [28]. Neydorf [29] has analysed the Stability issues of MAAT feeder airship
Table 6 Considered geographic locations and climatic data

* Average daily solar radiation on a horizontal plane

\begin{tabular}{|c|c|c|c|c|c|c|}
\hline & $\begin{array}{l}\text { Lat. } \\
\text { deg }\end{array}$ & $\begin{array}{l}\text { Air temperature } \\
{ }^{\circ} \mathrm{C}\end{array}$ & $\begin{array}{l}\text { Relative } \\
\text { humidity } \\
\%\end{array}$ & $\begin{array}{l}\text { Daily solar } \\
\text { radiation* } \\
\mathrm{kWh} / \mathrm{m}^{2} / \mathrm{d}\end{array}$ & $\begin{array}{l}\text { Wind speed } \\
\mathrm{m} / \mathrm{s}\end{array}$ & $\begin{array}{l}\text { Earth } \\
\text { temperature } \\
{ }^{\circ} \mathrm{C}\end{array}$ \\
\hline Bjornoya Island & 74.5 & -1.3 & $88.3 \%$ & 1.81 & 7.0 & 3.0 \\
\hline Oslo & 60 & 5.7 & $73.4 \%$ & 2.41 & 2.6 & 4.5 \\
\hline Torino & 45 & 11.6 & $69.5 \%$ & 3.67 & 1.5 & 7.3 \\
\hline Cairo & 30 & 21.4 & $58.1 \%$ & 5.38 & 4.0 & 24.5 \\
\hline Asmara & 15 & 24.6 & $53.3 \%$ & 5.93 & 4.0 & 27.6 \\
\hline Singapore & 0 & 26.7 & $83.3 \%$ & 4.45 & 1.7 & 26.6 \\
\hline
\end{tabular}


Fig. 1 Cost of the plant at different latitudes and interpolating third order curve

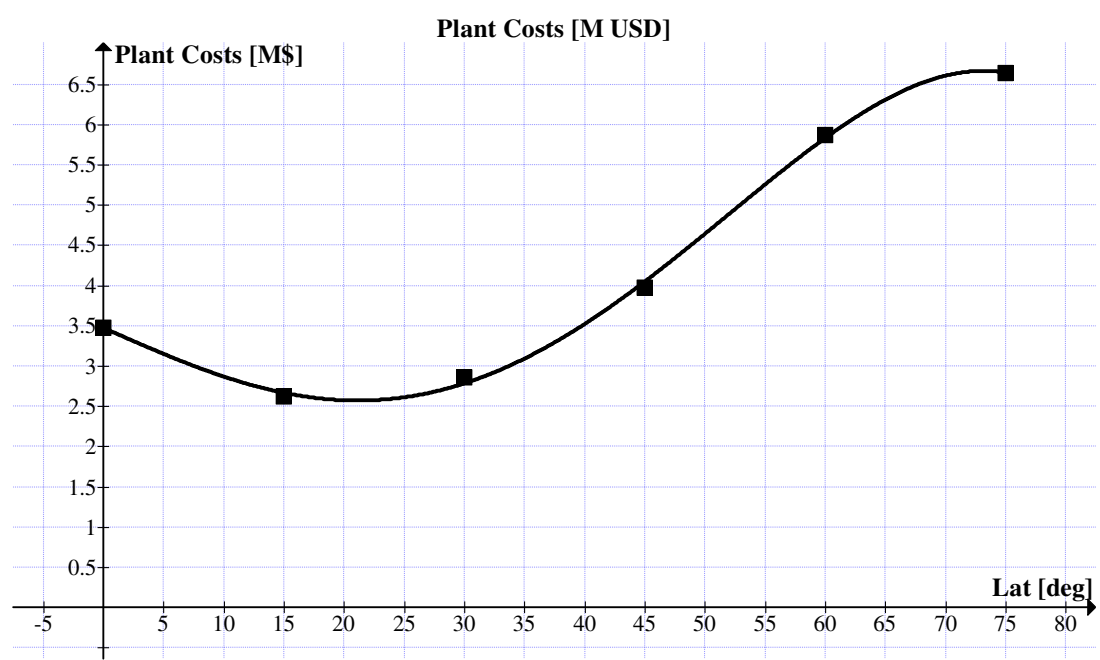

during vertical movements with wind disturbances. Pshikhopov[30] has considered planning of energy-efficient trajectories for the feeder with implementation of evolution algorithms.

Vizinho [31] has performed an effective computational analysis of the propulsive nacelle which needs to be used for the MAAT cruised propulsion. Vucinic, Gaviraghi and others [32] have analysed in depth the connection system and passenger exchange modes between cruise and feeder.

Another direction of development of the project is looking at methodological issues such as optimization systems. Ceruti [33] is analyzing multi-disciplinary design optimization with Heuristic Algorithms. Cerruti [34] analyses also how to apply innovatively rapid prototyping tools to facilitate wind tunnel testing of unconventional unmanned airships. Tuveri [35] is developing an innovative mesh based approach for the estimate the added masses to an unconventional unmanned airship.

On the other side Trancossi [36] has focused on the conceptual design methodologies to perform an effective system design optimization. Starting from the generalized formulation of the second principle defined by Adrian Bejan and defined Constructal Law [37, 38], he have

Table 7 Photovoltaic plant dimensions

\begin{tabular}{lllll}
\hline Latitude & $\begin{array}{l}\text { Hydrogen } \\
\text { productivity }\end{array}$ & $\begin{array}{l}\text { Number of PV } \\
\text { modules }\end{array}$ & $\begin{array}{l}\text { Electric } \\
\text { Power }\end{array}$ & $\begin{array}{l}\text { Effective } \\
\text { PV area }\end{array}$ \\
\hline Deg. & $\mathrm{m}^{3} / \mathrm{m}^{2}$ year & - & $\mathrm{kW}$ & $\mathrm{m}^{2}$ \\
Deg. & $\mathrm{m}^{3} / \mathrm{m}^{2}$ year & - & $\mathrm{kW}$ & $\mathrm{m}^{2}$ \\
0 & 36.6 & 6959 & 1391.6 & 10298.69 \\
15 & 48.5 & 5251 & 1050.2 & 7771.79 \\
30 & 44.5 & 5723 & 1144.6 & 8470.38 \\
45 & 32.1 & 7934 & 1586.8 & 11742.43 \\
60 & 21.7 & 11737 & 2347.2 & 17370.14 \\
75 & 19.2 & 13265 & 2652.8 & 19631.88 \\
\hline
\end{tabular}

developed a novel design method which can overcome the theoretical limits of the bottom-up design approach. He has finally proposed final formulations based on a dual cycle design method with a preliminary design method: the first aims to the definition of the optimal system on the basis of Constructal principle and second principle of Thermodynamics, the second aims to produce an effective optimization of the internal subcomponents of the system. This design methodology - defined Constructal Design for Efficiency - aims to finalize an optimal design which can solve the energetic issues related to the MAAT cruiserfeeder system. It has been previously applied to transport airship shapes with interesting results [39, 40] and on MAAT system [41, 42]. In particular, Trancossi is also working inside standardization committees on photovoltaic focusing on the characterization of photovoltaic modules for extreme conditions [43].

\section{Hydrogen use as buoyant gas}

The use of hydrogen as buoyant gas is a defined technical choice of the MAAT project. This technical choice is necessary especially for airships with a long airborne permanence, because of simple replacement of the gas which disperses into the environment.

It is possible to evaluate the convenience of hydrogen use both as buoyant gas and as energy storage system comparing it to helium and batteries for a large electrically propelled airship.

It has been considered a high altitude long permanence airship, which is a part (cruiser) of the MAAT cruiser-feeder architecture. Three phenomena have considered initial volume inflating (at ground), energy production and storage, gas replacement during service. It has been also evaluated the energy balance of the system for the initial reference discoid shape. Safety considerations has been also taken into account. 
Fig. 2 Payback times at various latitudes and interpolating curve

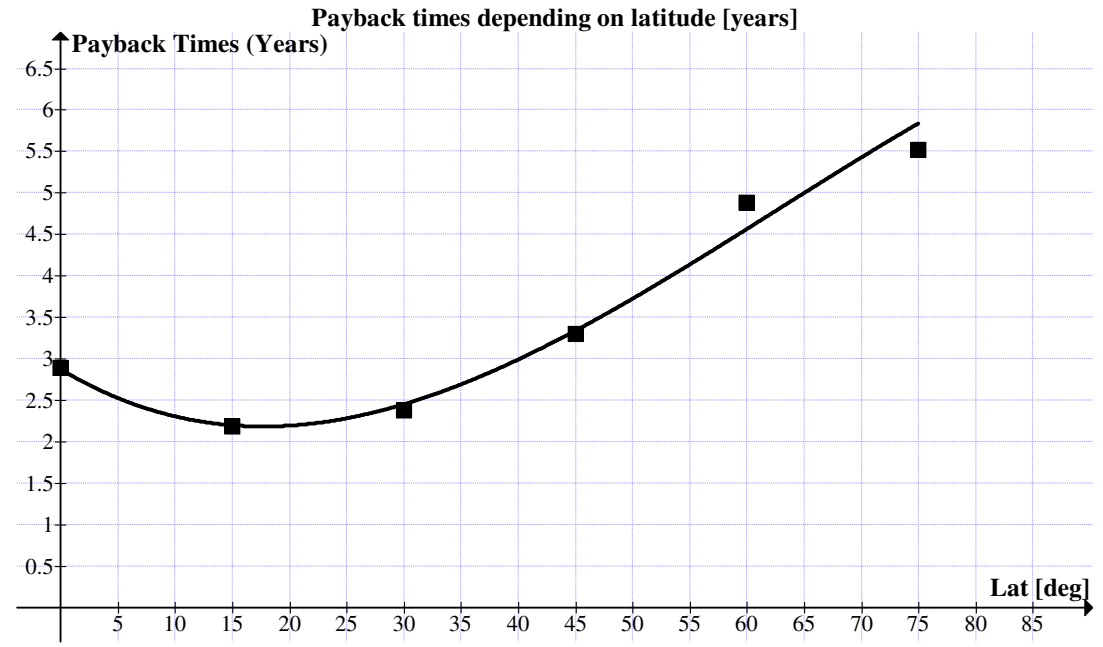

\section{General data}

This paper considers a large airship with the capacity to lift 300 passengers plus baggage and 20 people crew at $16 \mathrm{~km}$. An overall weight of $125 \mathrm{~kg}$ for passenger has estimated. A $5 \%$ buoyant gas overpressure has estimated in the balloon to maintain the shape, even in presence of wind. The operative altitude has estimated at $16 \mathrm{~km}$ and maximum ceiling of the system at $17 \mathrm{~km}$.

Atmospheric data have reported in Table 1.

Main physical parameters of the airship have been evaluated in Table 2. An overpressure about $5 \%$ has considered ensuring the possibility of the balloon system to keep the shape.

Both Hydrogen and Helium balloons has been estimated and it has been observed that helium balloons results about 1.084 times larger than hydrogen ones. The hydrogen mass has also been evaluated in 29.44 tons while helium mass in about 61.53 tons. A parameter, defined $\mathrm{V}_{\text {eff }}$, has defined for hydrogen and helium airships. It considers that the external volume of the system is larger than the volume of gas strictly necessary for buoyancy. A coefficient 1.1 has adopted in this evaluation because of the system is a cruiser/feeder. It presents more empty spaces than any other traditional airship system because of this architecture.

Table 8 Estimated costs for the plant

\begin{tabular}{lll}
\hline Photovoltaic modules & $\$ / \mathrm{kW}$ & 1,000 \\
Back-up system & $\$ / \mathrm{kW}$ & 300 \\
Installation & $\$ / \mathrm{kW}$ & 200 \\
Transmission lines & $\$ / \mathrm{kW}$ & 300 \\
Inverter & $\$ / \mathrm{kW}$ & 100 \\
Electrolysers & $\$ / \mathrm{kW}$ & 200 \\
Compression plant and Storage & $\$ / \mathrm{kW}$ & 400 \\
Total & $\$ / \mathrm{kW}$ & 2,500 \\
\hline
\end{tabular}

Changing shape airship architecture such as the ones evaluated in $[19,20]$ has evaluated. It has also evaluated an ellipsoid shape, which is characterised by the following relations:

$V=\frac{4 \pi}{3} \cdot a \cdot b \cdot c$

$A \simeq 4 \cdot \pi \cdot\left(\frac{a^{k} b^{\mathrm{k}}+a^{k} c^{k}+b^{k} c^{k}}{3}\right)^{1 / k}$

Area expressed by Eq. 2 is expressed by the Knud Thomsen formula which has a maximum error of 1,061, where $\mathrm{k}$ is a numerical constant equal to 1.6075.

It is possible to compare Helium and Hydrogen volume. The comparison is reported in Table 3. The following conventions have assumed: $V$ is the useful volume of buoyant gas for lift and $V_{\text {eff }}$ the effective volume used for aerodynamic calculations. The two semi axes on the horizontal plane $(x, y)$ have been assumed $a=b=150 \mathrm{~m}$. The constant $\mathrm{c}$ is considered variable with altitude. By this assumption, it is possible to evaluate the reference values used for calculation (Table 4).

\section{Initial airship inflation}

The initial inflation can be evaluated by assuming the masses of both helium and hydrogen.

In 2011, the Helium $99.9 \%$ the average market price in the U.S. $[44,45]$ can be estimated between 50 and 70 USD/MCF. It means a price between 1.77 and $2.47 \mathrm{USD} / \mathrm{m}^{3}$. For such a volume of hydrogen it is necessary an initial expense between 613000 USD and 855000 USD excluding losses. Some China suppliers have similar prices also. Prices exclude storage 
Fig. 3 Unitary losses as a function of operative altitude with high quality fabric

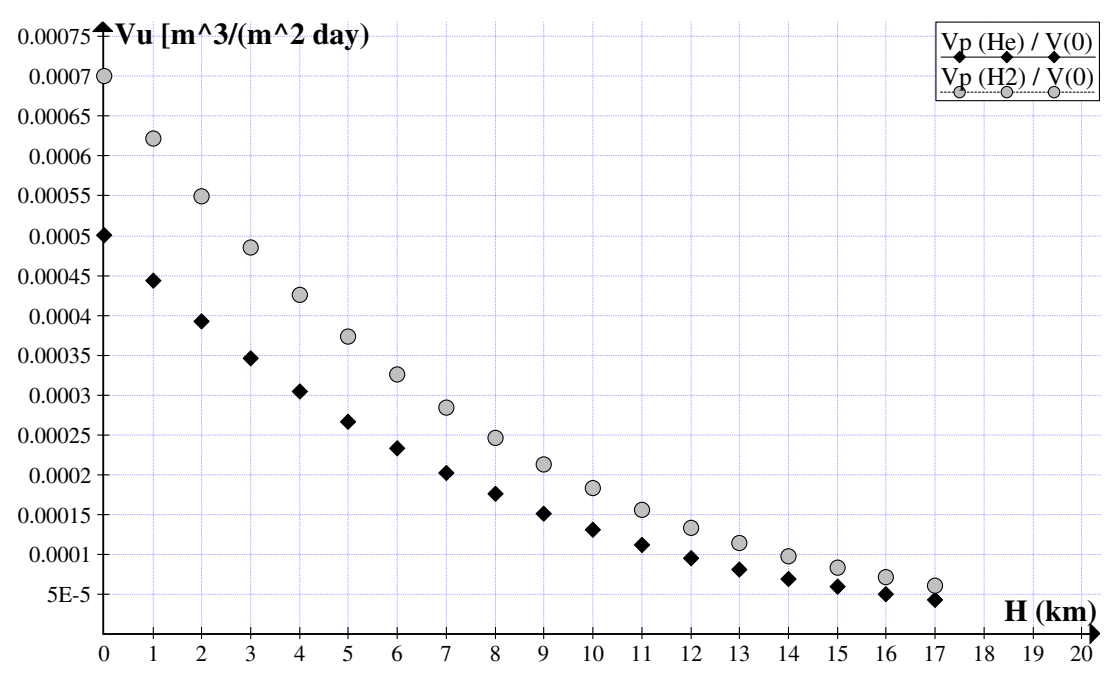

cylinders and delivery costs, which lead in Europe to much higher prices.

In a preceding paper, Dumas [43] has estimated that the necessary hydrogen can be produced in one year with a large photovoltaic facility with the characteristics reported in Table 5. It has evaluated the economic feasibility of photovoltaic hydrogen production that making a conservative hypothesis on the prices of hydrolytic hydrogen (evaluated one-fifth of average helium cost). For advanced solid polymer or alkaline electrolyser, the electric efficiency [46] of the industrial process overcomes $75 \%$.

A possible market price of hydrogen for airship inflation can be estimated (prudentially) the $25 \%$ of average helium cubic meter prices. It means that a cubic meter of Hydrogen is about $0.5 \$ / \mathrm{m}^{3}$ (a low price considering actual market standards). Considering that about $5 \mathrm{kWh}$ are necessary to produce $1 \mathrm{~m}^{3}$ of compressed hydrogen, it means the price of electricity can be considered $0.1 \$ / \mathrm{kWh}$.
Compressed hydrogen productivity has estimated in different locations and at different latitudes (Table 6). In particular sample locations has assumed on the northern hemisphere at $15^{\circ}$ step.

The hydrogen average annual productivity on a flat horizontal plan has estimated in terms of compressed hydrogen $[20,23,24]$ and shown as a function of latitude in Fig. 1.

It has also evaluated the plant dimensions (Table 7) according to the unitary costs specified in Table 5. The costs (Fig. 1) and payback times (Fig. 2) have been estimated. The dimensions have evaluated on the possibility of filling a large airship such as the one considered with the electrical production of a year.

Considering European costs of Energy a similar photovoltaic plant, even if very large, can have a very similar payback time considering the possibility of selling the electricity on the market at the same evaluated price of $0.1 \mathrm{USD} / \mathrm{kWh}$.
Fig. 4 Losses $\left[\mathrm{m}^{\wedge} 3 /\right.$ day $]$ as a function of operative altitude with high quality fabric and interpolating functions

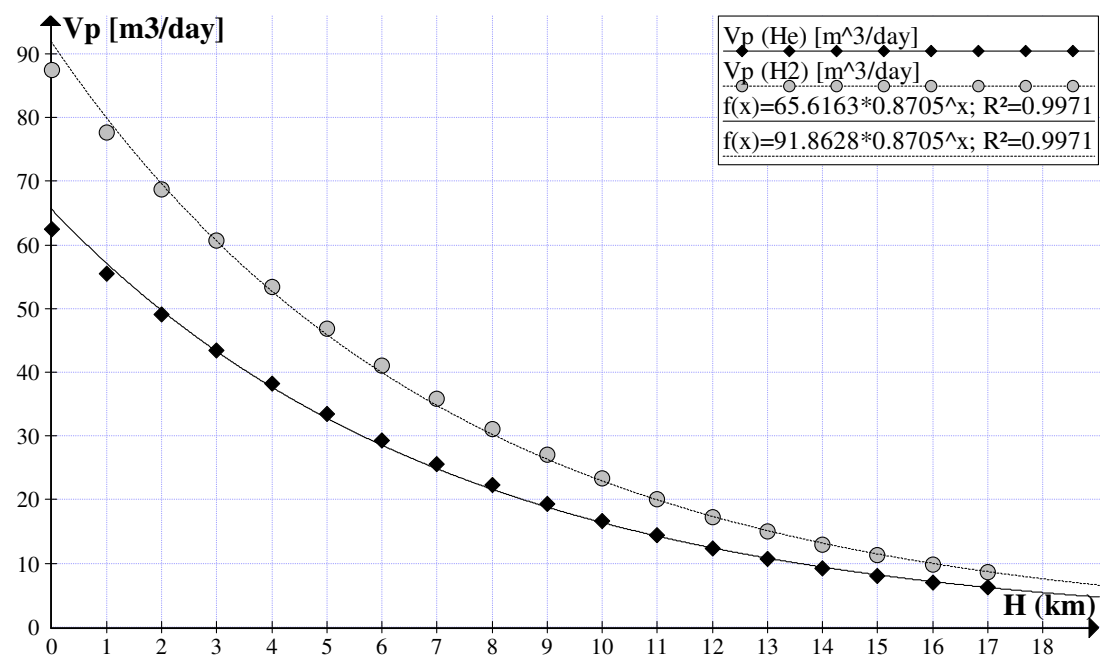


Fig. 5 Temperature CIRA 86 average annual values vs. Standard Atmosphere values

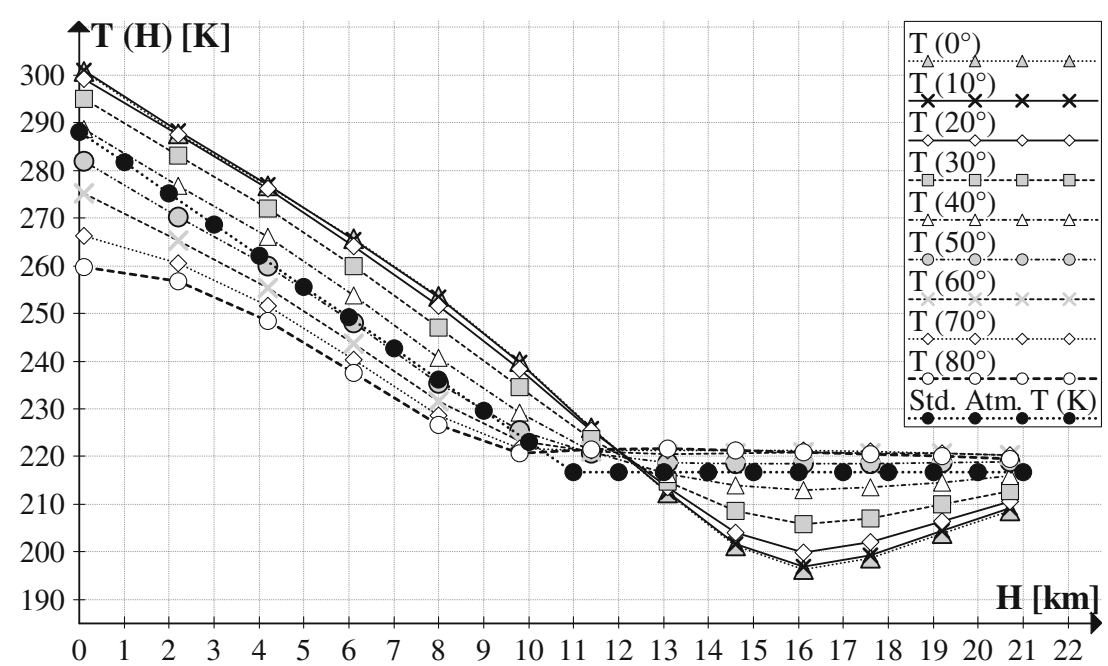

\section{Buoyant dispersion}

\subsection{Permeability}

An airship has continuous losses of gas by permeability. In scientific literature, different expressions can be found to describe permeability processes. The simplest way is to adopt the permeability coefficient [47], which can be defined as:

$P=\frac{(\text { quantity of permeant }) \times(\text { film thickness })}{(\text { area }) \times(\text { time }) \times(\text { pressure drop across the film })}$

This representation of permeability is very comfortable for an initial evaluation and especially because it permit a temperature dependent formulation. The case of a high altitude airship can be described by temperature dependent coefficients, because of the extreme variation of thermal conditions during missions.

Table 9 Permeability coefficient of various materials

\begin{tabular}{llll}
\hline & $\mathrm{P}(\mathrm{He})$ & $(\mathrm{P}(\mathrm{H} 2)$ & $\mathrm{P}(\mathrm{O} 2)$ \\
\hline Poly(ethylene) density $0.914 \mathrm{~g} / \mathrm{cm}^{\wedge}-3$ & $7.40 \mathrm{E}-13$ & $3.70 \mathrm{E}-13$ & $2.20 \mathrm{E}-13$ \\
Polyvinilecloride plasticized $10 \%$ & $1.30 \mathrm{E}-13$ & - & $3.83 \mathrm{E}-16$ \\
Polyvinilacetate & $4.95 \mathrm{E}-13$ & $2.99 \mathrm{E}-13$ & $1.36 \mathrm{E}-14$ \\
Poly(trifluorochloroethylene) & $7.05 \mathrm{E}-14$ & $5.10 \mathrm{E}-13$ & $3.00 \mathrm{E}-15$ \\
$\quad$ film 30 \% cristallinity & & & \\
Mylar A & $4.88 \mathrm{E}-14$ & $2.44 \mathrm{E}-14$ & $3.00 \mathrm{E}-15$ \\
Nylon 6 & - & $3.98 \mathrm{E}-14$ & $2.85 \mathrm{E}-15$ \\
Nylon 11 & $1.34 \mathrm{E}-13$ & $1.46 \mathrm{E}-13$ & - \\
Cellophane (relative humidity 43 \%) & $1.20 \mathrm{E}-15$ & - & $5.36 \mathrm{E}-16$ \\
\hline
\end{tabular}

The permeation of molecules through flawless polymers is the combination of two effects: the solution of a permeant in the polymer and diffusion of the dissolved permeant. The permeability coefficient is the product of the diffusion coefficient $\mathrm{D}$ and the solubility coefficient $\mathrm{S}$ :

$P=D \cdot S$

The permeability coefficient $\mathrm{P}$, the diffusion coefficient $\mathrm{D}$, and the solubility coefficient $\mathrm{S}$ can vary as a function of temperature, and exponential relations can express these relations:

$P=P_{0} \cdot e^{-\frac{E_{p}}{R T}} ; D=D_{0} \cdot e^{-\frac{E_{d}}{R T}} ; S=S_{0} \cdot e^{-\frac{E_{s}}{R T}}$

where $E_{p}$ is the activation energy of permeation, $E_{d}$ the activation energy of diffusion, and $\mathrm{E}_{\mathrm{s}}$ the heat of solution that have in SI units the dimension $[\mathrm{kJ} / \mathrm{mol}]$. Those data are tabled for many polymers and for many gasses and liquids. $P_{o}, D_{o}$ and $S_{o}$ are the multiplicative factors. $R$ is the gas constant; T is the temperature.

The permeability coefficient is determined for a given temperature by means of the multiplicative factor $P_{o}$ and the activation energy of permeation $E_{p}$. These data have been tabled by Pauly [47].

This permeability evaluation is important. Joints and defects need an accurate evaluation. In particular, data for some materials of interest for balloons are reported in Table 8 .

\section{Permeability evaluation of materials}

The above-enunciated theory about permeability allows an effective application to the airship shape, both for helium 
Table 10 Evaluation of dispersions for different polymers

\begin{tabular}{|c|c|c|c|c|c|c|}
\hline \multirow[t]{2}{*}{ Loses for a $20 \mu \mathrm{m}$ membrane } & \multicolumn{3}{|l|}{ Ground } & \multicolumn{3}{|l|}{$16 \mathrm{~km}$} \\
\hline & $\begin{array}{l}\mathrm{V}\left(\mathrm{H}_{2}\right) \\
{\left[\mathrm{m}^{3} \text { gas } / \mathrm{m}^{2} \mathrm{~h}\right]}\end{array}$ & $\begin{array}{l}\mathrm{V}(\mathrm{He}) \\
{\left[\mathrm{m}^{3} \text { gas } / \mathrm{m}^{2} \mathrm{~h}\right]}\end{array}$ & $\begin{array}{l}\mathrm{V}\left(0_{2}\right) \\
{\left[\mathrm{m}^{3} \text { gas } / \mathrm{m}^{2} \mathrm{~h}\right]}\end{array}$ & $\begin{array}{l}\mathrm{V}\left(\mathrm{H}_{2}\right) \\
{\left[\mathrm{m}^{3} \text { gas } / \mathrm{m}^{2} \mathrm{~h}\right]}\end{array}$ & $\begin{array}{l}\mathrm{V}(\mathrm{He}) \\
{\left[\mathrm{m}^{3} \mathrm{gas} / \mathrm{m}^{2} \mathrm{~h}\right]}\end{array}$ & $\begin{array}{l}\mathrm{V}\left(0_{2}\right) \\
{\left[\mathrm{m}^{3} \text { gas } / \mathrm{m}^{2} \mathrm{~h}\right]}\end{array}$ \\
\hline Poly(ethylene) density $0.914 \mathrm{~g} / \mathrm{cm}^{\wedge}-3$ & 7.13E-05 & $3.56 \mathrm{E}-05$ & $2.12 \mathrm{E}-05$ & $1.07 \mathrm{E}-05$ & 5.34E-06 & $3.18 \mathrm{E}-06$ \\
\hline Polyvinilecloride plasticized $10 \%$ & $1.25 \mathrm{E}-05$ & & 3.69E-08 & $1.88 \mathrm{E}-06$ & & 5.53E-09 \\
\hline Polyvinilacetate & 4.77E-05 & $2.88 \mathrm{E}-05$ & $1.31 \mathrm{E}-06$ & $7.15 \mathrm{E}-06$ & 4.32E-06 & $1.96 \mathrm{E}-07$ \\
\hline Poly(trifluorochloroethylene) film $30 \%$ cristallinity & $6.79 \mathrm{E}-06$ & 4.91E-05 & $2.89 \mathrm{E}-07$ & $1.02 \mathrm{E}-06$ & 7.37E-06 & 4.33E-08 \\
\hline Mylar A & 4.7E-06 & $2.35 \mathrm{E}-06$ & $2.89 \mathrm{E}-07$ & 7.05E-07 & $3.52 \mathrm{E}-07$ & 4.33E-08 \\
\hline Nylon 6 & & & & & $5.75 \mathrm{E}-07$ & 4.12E-08 \\
\hline Nylon 11 & $1.29 \mathrm{E}-05$ & $1.41 \mathrm{E}-05$ & & $1.94 \mathrm{E}-06$ & 2.11E-06 & \\
\hline Cellophane (relative humidity $43 \%$ ) & $1.16 \mathrm{E}-07$ & & $5.16 \mathrm{E}-08$ & $1.73 \mathrm{E}-08$ & & 7.74E-09 \\
\hline
\end{tabular}

and hydrogen. It can be assumed that the gas dispersion for permeability can be expressed as:

$M_{p}=\frac{P \cdot A \cdot t \cdot \Delta p}{s}$

Gas dispersion for the three critical gasses has calculated for $1 \mathrm{~m}^{2}$ of balloon surface and per hour of steady service.

The choice of material must be a good compromise of mechanical properties and gas dispersions. The best compromise solutions between mechanical properties and porosity are Mylar A and or Nylon rip-stop-polyurethane dual layer balloons.

It is possible to find on the market high-quality proprietary fabrics. For example, it can be cited 3-ply rip-stop nylon $108.5 \mathrm{~g} / \mathrm{m}^{2}$ made on rigorous standards with internal polyurethane balloon. It has not the typical problems of the polyurethane: the pinholes and the difficulties in reparation.

This material allows evaluating daily losses in STP conditions. Helium losses are about $2.510^{-4} \mathrm{~m}^{3}(273.15 \mathrm{~K}$; $\left.1,013 \times 10^{5} \mathrm{~Pa}\right) /\left(\mathrm{m}^{2}\right.$ day $)$. Hydrogen losses about $3.510^{-4} \mathrm{~m}^{3}$ $\left(273.15 \mathrm{~K} ; 1,013 \times 10^{5} \mathrm{~Pa}\right) /\left(\mathrm{m}^{2}\right.$ day $)$. The cited values do not consider an entire airship in service including losses due to the

Table 11 Example of massif regulation in the case of a thermal excursion in gas temperature $\pm 10^{\circ}$ between day and night

\begin{tabular}{lllll}
\hline Hydrogen & $\mathrm{T}[\mathrm{K}]$ & $\mathrm{V}\left[\mathrm{m}^{3}\right]$ & $\Delta \mathrm{V}\left[\mathrm{m}^{3}\right]$ & $\Delta \mathrm{M}$ gas $[\mathrm{kg}]$ \\
& 206.65 & 2368397 & -114609 & 1446 \\
& 216.65 & 2483006 & 0 & 0 \\
\multirow{4}{*}{ Helium } & 226.65 & 2597616 & 114610 & -1318 \\
& $\mathrm{~T}[\mathrm{~K}]$ & $\mathrm{V}\left[\mathrm{m}^{3}\right]$ & $\Delta \mathrm{V}\left[\mathrm{m}^{3}\right]$ & $\Delta \mathrm{M}$ gas $[\mathrm{kg}]$ \\
& 206.65 & 2579995 & -124849 & 2865 \\
& 216.65 & 2704844 & 0 & 0 \\
& 226.65 & 2829692 & 124848 & -3142 \\
\hline
\end{tabular}

junctions among different textile sheets (Blimpworks Airship USA). The considered overpressure is higher than the usual one $1-3 \%$ ).

\section{Gas dispersion evaluation in service}

The volume and surface defined in Table 4 allow evaluating the dispersion into service. An airship including junctions

Table 12 Difference of average energy productivity and energy used for propulsion $[\mathrm{kW}]$

\begin{tabular}{|r|r|r|r|r|r|r|}
\cline { 2 - 7 } $\mathrm{v}$ & Latitude $[\mathrm{deg}]$ & \multicolumn{4}{|l|}{} \\
\hline $\mathrm{m} / \mathrm{s}]$ & 0 & 15 & 30 & 45 & 60 & 75 \\
\hline 0 & 16198 & 15905 & 14281 & 11896 & 9317 & 7421 \\
\hline 1 & 16156 & 15864 & 14240 & 11855 & 9275 & 7379 \\
\hline 2 & 16032 & 15739 & 14115 & 11730 & 9151 & 7254 \\
\hline 3 & 15824 & 15531 & 13907 & 11523 & 8943 & 7047 \\
\hline 4 & 15533 & 15241 & 13617 & 11232 & 8652 & 6756 \\
\hline 5 & 15160 & 14867 & 13243 & 10858 & 8279 & 6382 \\
\hline 6 & 14785 & 14493 & 12869 & 10484 & 7904 & 6008 \\
\hline 7 & 14188 & 13895 & 12271 & 9886 & 7306 & 5410 \\
\hline 8 & 13335 & 13042 & 11418 & 9034 & 6454 & 4558 \\
\hline 9 & 12197 & 11904 & 10280 & 7895 & 5315 & 3419 \\
\hline 10 & 10740 & 10448 & 8824 & 6439 & 3859 & 1963 \\
\hline 11 & 8935 & 8643 & 7019 & 4634 & 2054 & 158 \\
\hline 12 & 6750 & 6457 & 4833 & 2449 & -131 & -2027 \\
\hline 13 & 4153 & 3860 & 2236 & -149 & -2728 & -4624 \\
\hline 14 & 1112 & 820 & -804 & -3189 & -5769 & -7665 \\
\hline 15 & -2403 & -2695 & -4319 & -6704 & -9284 & -11180 \\
\hline 16 & -6424 & -6716 & -8340 & -10725 & -13305 & -15201 \\
\hline 17 & -10982 & -11275 & -12899 & -15284 & -17863 & -19759 \\
\hline 18 & -16110 & -16402 & -18026 & -20411 & -22991 & -24887 \\
\hline 19 & -21837 & -22130 & -23754 & -26139 & -28718 & -30615 \\
\hline 20 & -28197 & -28489 & -30113 & -32498 & -35078 & -36974 \\
\hline
\end{tabular}

Gray cells indicates negative values 
Fig. 6 Average temperature excursion around operative altitude of $16 \mathrm{~km}$ (North hemisphere)

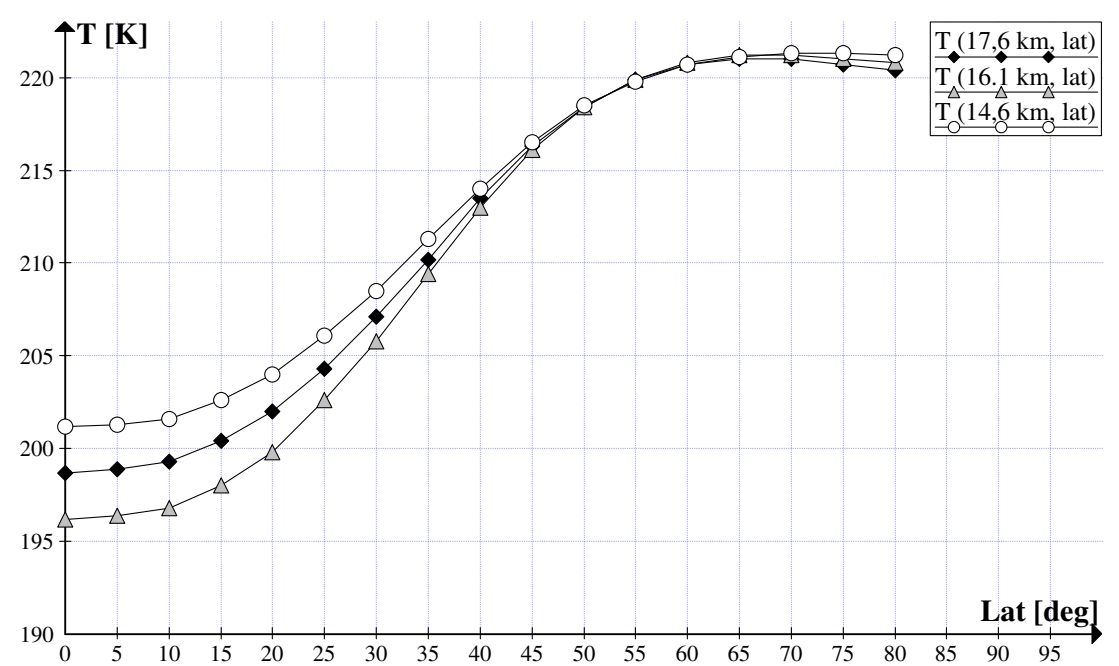

among sheets of the high-quality mentioned materials has been evaluated. Figure 3 shows the results. The overpressure has increased to $5 \%$ instead $1 \%$ evaluated by the producer.

By the results in Figs. 4 and 5 it is possible to see that long permanence airships with mission times longer than a week it losses can be significant.

The calculations show the losses because of permanence at high altitudes for a month. Helium losses are about $210 \mathrm{~m}^{3}$ and Hydrogen ones about $290 \mathrm{~m}^{3}$. These preliminary evaluations force to consider the impossibility to preserve the necessary overpressure and the shape geometry without any refill of gas. The losses increase also consistently in case of a lower quality fabric.

\section{Daily thermal excursion effects}

Another important volumetric effect is the daily thermal excursions and to location changes during travel. They have, with solar irradiance, large effects on the temperature and density of the buoyant gas. To compensate these daily thermal effects is necessary to preserve the operative altitude. The reference temperature of Standard Atmosphere model at stratospheric altitudes is about $-56^{\circ} \mathrm{C}$.

The simplest regulation of the volume against temperature variations is to vary the mass of gas in the balloon. The same pressure and volume preceding the thermal variation can be restored and preserved. Thermal controls have often used but volumetric are less expensive and less complex. They need only a sufficient reserve of gas.

For example, Tables 9, 10,11 and 12 shows the results of the calculations considering a thermal excursion of $\pm 10^{\circ}$. This example shows clearly that it is necessary a gas reserve also in mass to keep the volume by buoyant gas addition or subtraction.

This strategy of preserving the volume is interesting for hydrogen, because it is possible to avoid thermal actions on hydrogen lowering energetic costs and lessening the risks related to hydrogen thermal treatment plant.
Fig. 7 Electric Energy

Production average daily value $[\mathrm{MW}]$ for different latitudes at an altitude of $16 \mathrm{~km}$ a

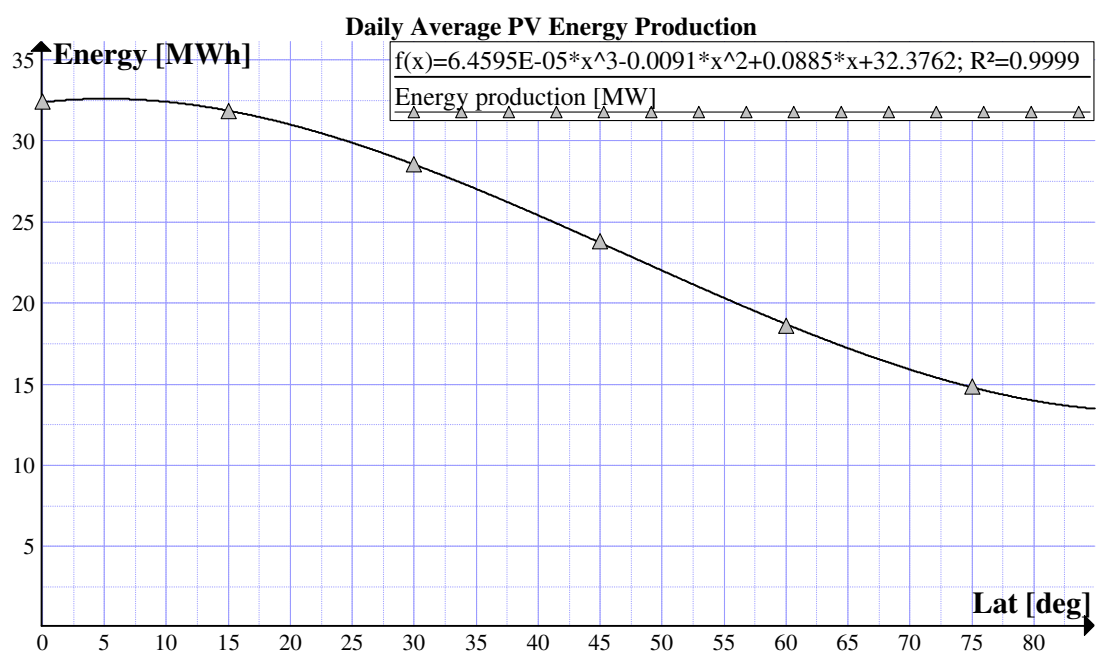




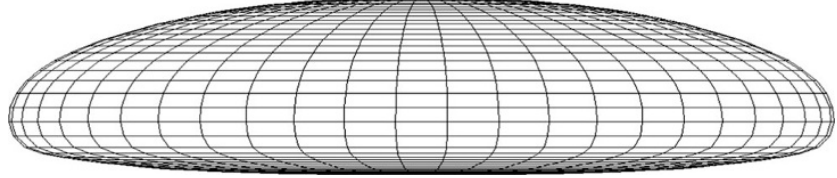

Fig. 8 The configuration of the reference shape

Another thermal effect needs a serious evaluation: the changes in air temperature and density, moving from one location to another. Figure 5 shows average temperature by Standard Atmosphere model and average temperature at different latitudes by CIRA Model.

Figure 6 shows the temperature variation around the operative altitude.

It shows clearly that an average temperature jump about $25^{\circ}$ must be considered. The daily thermal excursion has estimated in $10-12^{\circ} \mathrm{C}$ by considering data that are more accurate. By these values, the thermal effects on the system have estimated for this preliminary calculation.

In this case, the volume control by buoyant gas variation is easier than any other operation and much convenient for hydrogen airship.

\section{Energy needs for flight}

The energy production has estimated in a precedent paper [20] for square meter of photovoltaic surface at various latitudes. The photovoltaic surface has estimated about $61,000 \mathrm{~m}^{3}$. Daily average production has shown in Fig. 7 against latitude.

The considered discoid airship shape at 16.000 has shown in Fig. 8. The coefficient of drag of the shape $C_{D}$ and drag D has evaluated as a function of wind velocity at different diameters in a preceding paper [24]. It can be assumed conservatively a $C_{d, V}$ about 0.125 even if a lower one has been evaluated in the cited paper including their variation as a function of Reynolds number.

Following the method presented in such paper the aerodynamic forces and necessary power has estimated. Figure 9 presents the needed power at $16 \mathrm{~km}$ against relative velocity of the airship and third order interpolating function.

The held values allow verifying the average production of photovoltaic energy. The use of compressed hydrogen storage and fuel cells for conversions, together with batteries for emergency has assumed. A reference efficiency of the energy caption, storage and conversion has considered about $50 \%$.

Calculations have realised for $24 \mathrm{~h}$ of service at the annual mean relative speed of the considered airship. The energy needs have evaluated and subtracted to the needs for daily operations at constant velocity. The values are reported at an altitude of $16 \mathrm{~km}$ for different relative velocities. It has noted that the system must preferably move in the main direction of high altitude winds. In other cases, it can only remain in hovering conditions or being moved by high altitude winds passively.

The results force to consider a conservative hypothesis. The airship can move at an average velocity. It is equal to the average wind velocity in the selected location plus a seasonal value depending on photovoltaic energy high altitude caption.

Average speeds have evaluated by the results of these elementary calculations. Detailed calculations could be performed on daily, weekly or monthly photovoltaic productivity.

The operative velocity can then be plotted in Fig. 10 on average annual basis, taking data by the values of the velocity of winds by CIRA model.

\section{General considerations and future advances}

This paper presents a problem and analyses it drawing a methodological model of work for the future activities related to the MAAT project.
Fig. 9 Required power $\mathrm{kW}$ at different relative velocities

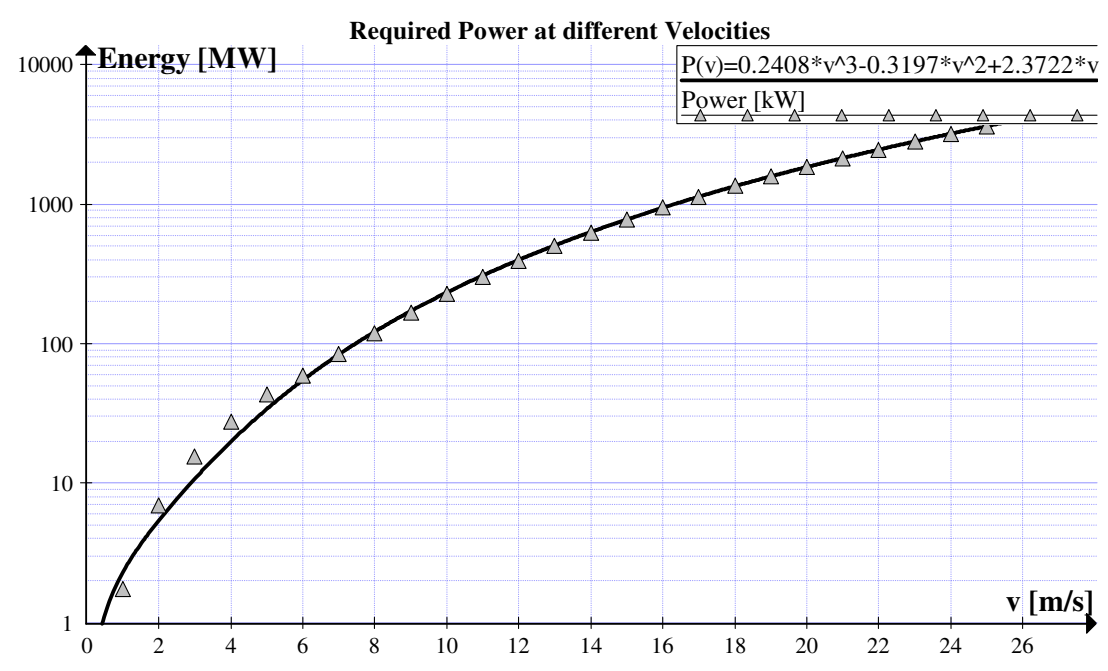


Fig. 10 Average velocity at an altitude of $16 \mathrm{Km}$ at different latitudes

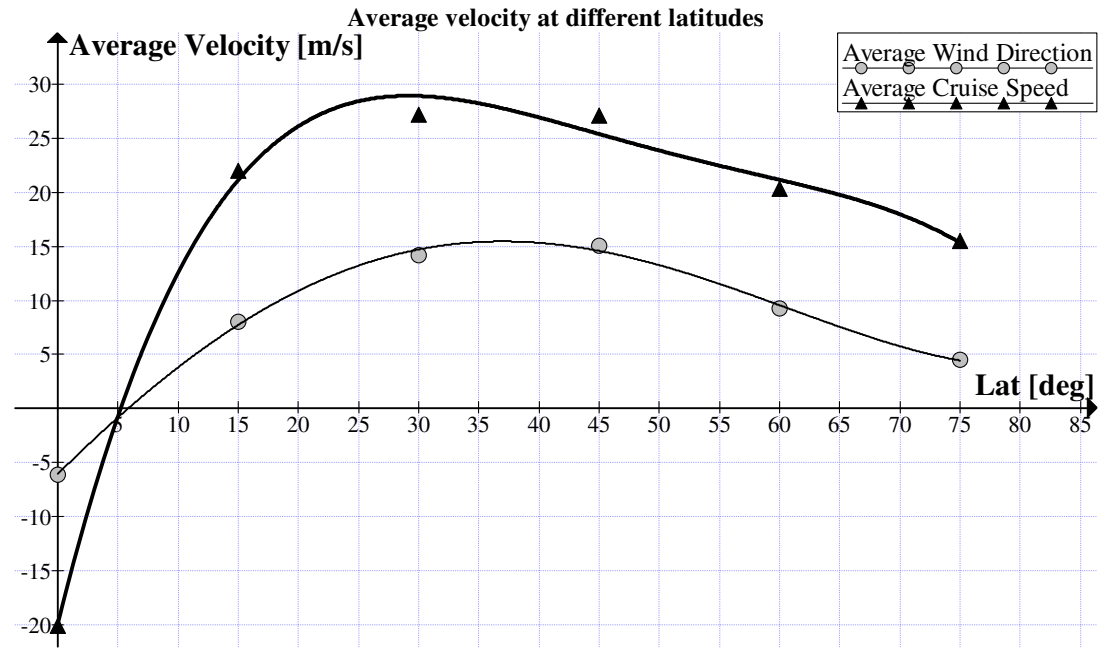

The mission profiles require a more accurate analysis of the velocities of the winds at different altitude and an effective mapping of the jet streams. It will be one of the primary efforts of further activities, which will define the ideal shape of the cruiser and the mission profiles.

The optimization of the shape and operation connected problems. They are the core of the development of the MAAT cruiser/feeder project. This paper present a method for the calculations necessary to minimize of energy needs and volume through an effective step by step optimisation.

Future activity will require also a detailed study of adiabatic phenomena that takes place during vertical movements, especially relating the feeder behaviour. An airship is subject during vertical movement to heating and cooling phenomena. Considering the vertical motion of an airship or of a balloon, it can be easily demonstrated that it changes its average temperature during expansion/ compression processes. Some hypothesis are required. They are in brief:

1. thermal exchanges of the balloon during the vertical movement are negligible,

2. the balloon can be considered as an air parcel.

3. changes in temperature result from either expansion or contraction

Such a process can be described by the first principle of thermodynamics and its governing equations are:

$\mathrm{dq}=0 \Rightarrow\left\{\begin{array}{l}\mathrm{V}=\cos \mathrm{t} \rightarrow \mathrm{c}_{\mathrm{v}} \mathrm{dT}+\mathrm{pd} \alpha=0 \\ \mathrm{P}=\operatorname{cost} \rightarrow \mathrm{c}_{\mathrm{p}} \mathrm{dT}-\alpha \mathrm{dP}=0\end{array}\right.$

In particular it can be considered an adiabatic process described by Poisson Eq. (7), which can be obtained by ideal gas equation:
$\frac{\mathrm{T}_{\text {final }}}{\mathrm{T}_{\text {initial }}}=\left(\frac{\mathrm{p}_{\text {final }}}{\mathrm{p}_{\text {initial }}}\right)^{\mathrm{R}_{\mathrm{d}} / \mathrm{c}_{\mathrm{p}}}$

Using numerical interpolations of the Standard Atmosphere values it is possible to evaluate the theoretical adiabatic temperature reached by the balloon. It relates the initial conditions of temperature and pressure to the final temperature and pressure. In calculations it can be assumed the hydrogen gas constant $R_{d}=4124 \mathrm{~J} / \mathrm{kg} \mathrm{K}$ and the specific heat $c_{p}=14.25 \mathrm{~J} / \mathrm{kg} \mathrm{K}$. It is in particular necessary to define an adequate model of the system and the heating/cooling apparatus to maintain the temperature of the gas in an acceptable range.

Adiabatic heating/cooling processes together with the heat transfer processes between the internal gas and the exterior one is an argument which needs to be analysed in depth. This activity will be interesting in the future especially to create an exact model of the vertical motion of the feeder.

Together it is necessary the job on controls.

\section{Conclusions}

This paper aims to show that hydrogen is fundamental for the future of airships. They are suffering large problems because of high costs of helium.

Hydrogen, which can be produced on board, simplifies the management of airship during long missions. It ensures the possibility of a continuous refilling of spread gas, even if hydrogen has higher dispersions than helium.

It has demonstrated that today prices of the photovoltaic hydrogen are the most economic choice for airship filling. Estimating a cost of electricity up to $0.1 \mathrm{USD} / \mathrm{kWh}$ it has shown that a photovoltaic plant for hydrogen production ensures a valid alternative to helium. 
It has demonstrated that a mix of storage technologies can perform the best performances and flexibility. Hydrolyser and fuel cells can perform the basic needs and batteries ensure a fast acting and flexible system. Together they ensure acceptable performances even with non-optimised shapes.

In this paper it has been considered the possibility of using hydrogen for airship volume. It is another important development for the future hydrogen airships. It is necessary because it is needed to increase system safety by removing any air ballonet inside the volume of the hull.

Acknowledgments The present work was performed as part of Project MAAT | Multibody Advanced Airship for Transport | with ref. 285602, supported by European Union through the 7th Framework Programme.

Open Access This article is distributed under the terms of the Creative Commons Attribution License which permits any use, distribution, and reproduction in any medium, provided the original author(s) and the source are credited.

\section{References}

1. CORDIS (2011) Multibody Advanced Airship for Transport, CORDIS (COmmunity Research and Development Information Service), European Commission, Brussels http://cordis.europa. $\mathrm{eu} / \mathrm{search} /$ index.cfm? fuseaction $=$ proj.document\&PJ_LANG $=$ E N \& P J R C N = 12149444 \& p i d = 8 \& q $=$ 1DBC26FEDA78A901E7C4E7F31040F180\&type $=$ adv

2. CORDIS (2011) MAAT Project - Multibody Advanced Airship for Transport - has started, CORDIS Wire, CORDIS (COmmunity Research and Development Information Service), European Commission, Brussels http://cordis.europa.eu/wire/index.cfm? fuseaction=article.Detail\&ren=28667

3. Dumas A, Trancossi M, Madonia M and Giuliani I (2011) "Multibody Advanced Airship for Transport," SAE Technical Paper 2011-01-2786, doi:10.4271/2011-01-2786

4. Dumas A, Madonia M, Giuliani I and Trancossi M (2011) "MAAT Cruiser/Feeder Project: Criticalities and Solution Guidelines," SAE Technical Paper 2011-01-2784, doi:10.4271/2011-01-2784

5. Lewitt EH (1925) The rigid airship, "A treatise on the design and performance". Sir Isaac Pitman and Sons Ltd., London

6. Warner EP (1926) "Aerostatics". The Ronald Press Co, New York

7. Kreider JF (1975) "Mathematical Modeling of High Altitude Balloon Performance." AIAA-75-1385. AIAA 5th Aerodynamic Deceleration Systems Conference, Albuquerque NM, Nov 17-19 1975

8. Khoury GA, Gillett JD (1999) Airship technology. Cambridge University Press, London

9. Raymer DP (2006) Aircraft design: A conceptual approach, AIAA, 4th edition Hardcover, 869 pp., ISBN-10: 1563478293

10. Krausman JA (1995) Investigation of various parameters affecting altitude performance of tethered aerostats, AIAA Paper 1995-1625, May

11. Colozza A (2003) Initial feasibility assessment of a high altitude long endurance airship. NASA/CR 2003-212724

12. Colozza A (2005) High-altitude, long-endurance airships for coastal surveillance, NASA/TM-2005-213427

13. Dumas A, Anzillotti S and Trancossi M (2008) Photovoltaic stratospheric isle for conversion in hydrogen as energy vector. Proc IME G J Aerosp Eng, .E.P., ISSN 0954-4100
14. Dumas A, Pancaldi F, Anzillotti and Trancossi M (2009) "High altitude platforms for telecommunication: design methodology," SAE Tech. Paper 2009-01-3159, doi:10.4271/2009-01-3159

15. Aglietti GS, Markvart T, Tatnall AR, Walker SJ (2008) Solar power generation using high altitude platforms feasibility and viability. Prog Photovolt: Res Appl:16,4:349,359, doi:10.1002/pip.815

16. Ilieva G, Páscoa J, Dumas A, Trancossi M (2012) A critical review of propulsion concepts for modern airships. Cent Eur J Eng 2(2):189 200

17. Dumas A, Anzillotti S, Madonia M and Trancossi M (2011) "Effects Of Altitude On Photovoltaic Production Of Hydrogen", ASME 5th International Conference On Energy Sustainability", Esfuelcell2011 2011-54624, August 7-10, 2011, Washington, Dc, USA

18. Dumas A, Trancossi M and Anzillotti S (2010) An airship design methodology based on available solar energy in low stratosphere". International Mechanical Engineering Congress And Exposition 2010, Vancouver Canada, 12-18 November 2010, Imece2010-38931

19. Trancossi M, Dumas A, Madonia M, Pascoa J et al (2012) Fire-safe airship system design. SAE Int J Aerosp 5(1):11-21. doi:10.4271/ 2012-01-1512

20. Dumas A, Trancossi M, Madonia M, Anzillotti S (2013) Photovoltaic production of hydrogen at stratospheric altitude. J Sol Energy Eng 135(1):1. doi:10.1115/1.4007357

21. Pshikhopov V, Medvedev M, Neydorf R, Krukhmalev V et al. (2012) "Impact of the feeder aerodynamics characteristics on the power of control actions in steady and transient regimes," SAE Technical Paper 2012-01-2112, doi:10.4271/2012-01-2112

22. Pshikhopov V, Krukhmalev V, Medvedev M and Neydorf R (2012) "Estimation of Energy Potential for Control of Feeder of Novel Cruiser/Feeder MAAT System," SAE Technical Paper 2012-012099, doi:10.4271/2012-01-2099

23. Dumas A, Trancossi M, Madonia M (2012) Energetic design and optimization of a large photovoltaic stratospheric unconventional feeder airship. SAE Int J Aerosp 5(2):354-370

24. Dumas A, Trancossi M, Madonia M, Pascoa J and others (2012) "CFD analysis and optimization of a variable shape airship," Proceedings of ASME IMECE2012, 2012 ASME IMECE 2012, November 9-15, Huston, Texas, USA

25. Khoshnoud F, Chen YK, Calay RK (2013) On power and control systems of the multibody advanced airship for transport. Int J Model Identif Control 18-4:313-322

26. Smith T, Bingham C, Stewart P, Allarton R, Steward J (2013) Energy harvesting and power network architectures for the multibody advanced airship for transport high altitude cruiser-feeder airship concept. Proc IME G J Aerosp Eng 227:586-598. doi:10.1177/ 0954410012469319

27. Smith T, Bingham C, Stewart P, Allarton R and Steward J (2012) "MAAT high altitude cruiser feeder airship concept," Electrical Systems for Aircraft, Railway and Ship Propulsion, ESARS 2012; Bologna; Italy; 16 October 2012 through 18 October 2012; Code 95414

28. Voloshin V, Chen Y, Neydorf R, Boldyreva A (2013) “Aerodynamic Characteristics Study and Possible Improvements of the MAAT Feeder Airship" SAE Tech. Paper n. 2013-01-2112, with oral presentation at SAE Aerotech 2013, Montreal

29. Neydorf R, Sigida Y, Voloshin V, Chen Y (2013) "Stability Analysis of the MAAT Feeder Airship During Ascent and Descent with Wind Disturbances", SAE Tech. Paper n. 2013-01-2111, with oral presentation at SAE Aerotech 2013,, Montreal

30. Pshikhopov VKh, Krukhmalev VA (2013) Planning of energyefficient trajectories of flight of stratospheric feeder-airship of multybody transport system MAAT - Don J Eng- 2013.-- №2

31. Vizinho R, Pascoa JC, Silvestre M (2013) "High Altitude Transitional Flow Computation for a Propulsion System Nacelle of MAAT Airship", SAE Tech. Paper n. 2013-01-2268, with oral presentation at SAE Aerotech 2013, 13ATC-0342, Montreal 
32. Vucinic D, Sunol A, Trancossi M, Dumas A, Gaviraghi G (2013) "MAAT Cruiser/Feeder Airship: Connection and Passenger Exchange Modes", SAE Tech. Paper n. 2013-01-2113, with oral presentation at SAE Aerotech 2013, 13ATC-0342, Montreal

33. Ceruti A, Voloshin V, Marzocca P (2013) "Multi-Disciplinary Design Optimization of Unconventional Airship Configurations with Heuristic Algorithms," 54th AIAA/ASME/ASCE/AHS/ASC Structures, Structural Dynamics, and Materials Conference, April 2013, Boston, MA

34. Cerruti A, Marzocca P, Stockbridge K (2013) "Rapid Prototyping as a Tool to Support Wind Tunnel Testing of Unconventional Unmanned Airships", SAE Tech. Paper n. 2013-01-2193, with oral presentation at SAE Aerotech 2013, 13ATC-0342, Montreal

35. Tuveri M, Ceruti A, Persiani F, Marzocca P (2013) “A Mesh Based Approach for Unconventional Unmanned Airship Added Masses Computation", SAE Tech. Paper n. 2013-01-2113, with oral presentation at SAE Aerotech 2013, 13ATC-0342, Montreal

36. Bejan A, Lorente S (2005) The constructal law and the thermodynamics of flow systems with configuration. Int J Heat Mass Transf 47(14-16):3203-3214

37. Bejan A, Lorente S (2008) Design with constructal theory. Wiley, New York

38. Bejan A, Zane JP (2012) Design in nature. Doubleday, New York

39. Bejan A (1997) Advanced engineering thermodynamics, 2nd edn. Wiley, New York
40. Trancossi M, Dumas A, Madonia M and Hadjidimitriou S (2013) “ Energetic analysis of a photovoltaic airship with variable volume", Proceedings of $7^{\circ}$ Congresso Nazionale AIGE - Rende (Cosenza), 10-11 Giugno 2013

41. Dumas A, Trancossi M and Madonia M (2012) Energetic Design and optimization of a large photovoltaic stratospheric unconventional feeder airship, SAE Technical Paper 2012-01- 2166, doi:10.4271/ 2012-01-2166

42. Trancossi M (2011) "Testing Performance, Weathering and Aging of Photovoltaic Modules", ASME 2011 5th International Conference on Energy Sustainability, Parts A, B, and C, ISBN: 978-0-7918-5468-6

43. Dumas A, Trancossi and Madonia M (2012) "Hydrogen Airships: a necessary return because of high costs of Helium", ASME 2012 International Mechanical Engineering Congress and Exhibition", IMECE 2012, November 9-15, 2012, Huston, TX, USA - in press

44. National Research Council (2000) Economics of the helium market, the impact of selling the federal helium reserve. The National Academies Press, Washington, DC

45. Airship Association (2011) Private communication, London, United Kingdom, October 2011

46. NREL (2004) Technology Brief: Analysis of Current-Day Commercial Electrolysers", NREL, National Renewable Energy Laboratory, Los Alamos, NM, USA

47. Pauly S (1999) Permeability and diffusion data, In: Brandrup J, Immergut EH, Grulke EA Polymer Handbook, 4th Ed. Brandr 